\title{
Discussion on the construction of disaster prevention green infrastructure network planning
}

\author{
Feng $\mathrm{Yao}^{1,2, a *}$, Zhang Lusi ${ }^{1,2, b}$, Shao Mingqi ${ }^{1,2, \mathrm{c}}$, Meng $\mathrm{Qi}{ }^{1, \mathrm{~d}}$ \\ ${ }^{1}$ School of Architecture of Harbin Institute of Technology, Xidazhi Street 66\#,Nangang District, \\ Harbin, Heilongjiang Province150006, China \\ ${ }^{2}$ Institute of Landscape and Ecological Planning of Architecture, Harbin Institute of Technology, \\ Xidazhi Street 66\#,Nangang District, Harbin, Heilongjiang Province150006, China \\ a1417834308@qq.com, b943364366@qq.com, '939868310@qq.com, dmengqi@hit.edu.cn \\ * Corresponding author. E-mail address: 1417834308@qq.com
}

\section{Keywords: Disaster Prevention; Green Infrastructure; Network Planning}

\begin{abstract}
This paper use the advanced experience of Japan in the area of disaster prevention green space planning and construction and, look at the status, gaps and challenges of China's construction and planning of Green Infrastructure, present the new thinking direction about the construction of disaster prevention green space combine with Green Infrastructure. Taking the construction of the disaster prevention green infrastructure network planning of Majiagou River in Harbin as an example and put forward related strategies.
\end{abstract}

In 2011, after “3·11” East Japan earthquake, disaster areas that rely on all levels of green space, open space, and the campus in disaster prevention and evacuation system, which amount to more than 2400 shelters, provide protection for 550 thousand people at most as shelters. However, in the initial stage after the Wenchuan earthquake, a large number of residents can only squeeze in the red line inside the road, because of the lack of adequate shelter in the range by the walking scale. This phenomenon shows that when the earthquake, fire and other devastating sudden urban disasters occur, urban green space and other open space play an important role in disaster prevention.

Urban disasters usually have the characteristics of burst, diversity and companion, which requires that the planning and construction of urban disaster prevention shelter should have the function of coping with all kinds of unexpected events. Moreover, the number, scale and distribution of the disaster prevention green space and evacuation system is closely related to the number and the distribution of local residents. Therefore, this paper analyzes the current situation of China's national planning and construction of disaster prevention green infrastructure, analyzes the gaps and challenges, combine with disaster prevention planning and construction of urban green infrastructure to provide a new thinking direction.

\section{The experience of foreign disaster prevention green space planning and construction}

In 19 Century, Chicago and Boston have happened a succession of fires, in the post disaster reconstruction plan, Chicago park system and Boston Park system separated high density urban areas through the park road and use open space system to prevent the spread of fire. This strategy also improve the city's ability to resist natural disasters, this planning method fully develop the functions of parks as well as other green space, it is a pioneer in the planning of disaster prevention green space system.

After the Great Kanto earthquake in 1923, Japan look at the ideas and practices of Chicago park system planning to develop the first systematic planning of green space system. From 1972, Japan has carried on 6 times of "the city park construction plan" and gradually transformed more and more urban parks to disaster prevention parks and completed the construction of the urban refuge system rely on green space system. After the Hanshin Awaji Earthquake in 1995, Japan has reviewed the rationality of the layout of City disaster prevention park and the completeness of disaster prevention facilities to enhance the disaster prevention function of urban park green space, it also continued to 
extend the area of disaster prevention park at the same time. Furthermore, the Japanese government has provided enough legal guarantee and fund guarantee for the promotion of urban disaster prevention green space system planning and construction. First of all, Japan has introduced a series of regulatory documents include the "Urban parks code" "Urban green space Preservation code" about some detailed provisions of the disaster prevention park planning and design as well as construction of the relevant issues. Secondly, Japanese government has provided financial support for the construction of disaster prevention park green space, including 1/3 costs of land acquisition and 1/2costs of facilities construction. Since 1995, Japan appropriate 200 billion yen every year , using to build a number of disaster prevention park respectively in the major cities.

\section{Disaster prevention green space system planning and construction in China}

From the experience of Japan, Taiwan has began Taipei city planning and some related research of disaster prevention system planning and disaster prevention space system in last century 90's. The research on the earthquake resistant efficiency of urban green space in China is began to be first seen in 1990s, most of the theoretical research has focused on the disaster prevention planning system and construction management experience in Japan, Europe and the United States. In the last few years, some researcher such as Liu Haiyan and Xie Junfei has used the spatial analysis of GIS combined with the population distribution density, respectively carry out qualitative and quantitative analysis research on the hedging ability of city park in Xi'an and Beijing to provide a reliable basis for disaster prevention green space planning.

The laws and regulations relating to the construction of urban green space planning and construction in China include "Law of the people's Republic of China on urban and rural planning", "Urban greening regulations and Regulations on urban green planning and construction", "The park design code". "The system of urban green space system planning (Trial) (2002)" is still lack of the requirements for the urban disaster prevention green space planning, which make most of the urban green space system planning in our country has no consideration about the disaster prevention green space planning. The "City earthquake disaster prevention planning regulations "Article9 :”To develop city earthquake disaster prevention planning should include the municipal and district level suspension channel and the evacuation site (such as green square, etc.) and personnel evacuation and evacuation center measures " has been implemented since 2003. After the 2008 Wenchuan earthquake, the Ministry released "Strengthening the urban green space system construction, improve the ability of urban disaster prevention and mitigation", besides, put forward the organization and leadership of specific suggestions, guidelines and requirements in respect of urban green space system in the role of disaster prevention, planning, construction, facilities maintenance and disaster prevention work, which provide guidance on regulations for the planning and construction of disaster prevention green space and play an important role in achieving urban green space planning regulations system. Beijing and other provinces and cities have also introduced the corresponding regulations, for the construction of disaster prevention system to provide legal protection (Table 1). Following the first disaster prevention park_—Beijing Yuan Dadu City Wall Relics Park built in 2003, Beijing, Xi'an and other places has carried out some work of disaster prevention planning and make some progress. 
Table 1 - The construction of disaster prevention green space in Beijing

\begin{tabular}{|c|c|c|}
\hline year & Event & content \\
\hline 2001 & $\begin{array}{l}\text { Beijing City, the } \\
\text { implementation of" the } \\
\text { people's Republic of China } \\
\text { earthquake disaster reduction } \\
\text { method" }\end{array}$ & $\begin{array}{l}\text { Consider the need for emergency evacuation of } \\
\text { personnel in the earthquake and the need to } \\
\text { hedge, and to set aside channels and necessary } \\
\text { green space, square and open space }\end{array}$ \\
\hline 2002 & Beijing City Park Ordinance & $\begin{array}{l}\text { Provided for the park with the function of } \\
\text { disaster prevention }\end{array}$ \\
\hline 2003 & $\begin{array}{l}\text { Built the first disaster } \\
\text { prevention park }\end{array}$ & Beijing Yuan Dadu City Wall Relics Park \\
\hline 2005 & $\begin{array}{l}\text { Beijing center city earthquake } \\
\text { and other disaster emergency } \\
\text { shelters (outdoor) planning } \\
\text { program }\end{array}$ & $\begin{array}{l}\text { Transform the eight major urban areas of the park } \\
\text { green space into disaster evacuation area that } \\
\text { equipped with emergency hedge facilities in the } \\
\text { true sense }\end{array}$ \\
\hline
\end{tabular}

Table 2. Distribution of disaster prevention park in the center area of Beijing

\begin{tabular}{|c|c|c|c|c|c|c|c|}
\hline & Name & acreage & $\begin{array}{l}\text { Number of } \\
\text { refugee[en } \\
\text { thousand] }\end{array}$ & & Name & acreage & $\begin{array}{l}\text { Number of } \\
\text { refugee[ten } \\
\text { thousand)] }\end{array}$ \\
\hline 1 & $\begin{array}{l}\text { Ditan Park outside } \\
\text { the park }\end{array}$ & 5.4 & 2.7 & 16 & $\begin{array}{l}\text { Huangchenggen } \\
\text { Ruins Park }\end{array}$ & 9 & 4.5 \\
\hline 2 & $\begin{array}{l}\text { Xibianmen green } \\
\text { place }\end{array}$ & 4.7 & 1.3 & 17 & $\begin{array}{l}\text { Ming City Wall } \\
\text { Ruins Park }\end{array}$ & 15.5 & 6 \\
\hline 3 & Yu Ting Park & 3.7 & 1.5 & 18 & $\begin{array}{l}\text { South Road } \\
\text { Green space }\end{array}$ & 3.7 & 1.5 \\
\hline 4 & $\begin{array}{l}\text { Changchun Yuan } \\
\text { Park }\end{array}$ & 1.4 & 0.6 & 19 & $\begin{array}{l}\text { Cuifangyuan } \\
\text { Green space }\end{array}$ & 0.7 & 0.5 \\
\hline 5 & Fengxuan Park & 3.3 & 1.5 & 20 & $\begin{array}{l}\text { The longevity } \\
\text { Park }\end{array}$ & 3.3 & 1.5 \\
\hline 6 & $\begin{array}{l}\text { Xiannongtan green } \\
\text { space }\end{array}$ & 0.6 & 0.3 & 21 & South axis & 10.4 & 4.7 \\
\hline 7 & $\begin{array}{l}\text { Yuan Dadu City } \\
\text { Wall Relics Park }\end{array}$ & 67 & 19 & 22 & Sun Palace Park & 37 & 11 \\
\hline 8 & $\begin{array}{l}\text { Anzhenyong river } \\
\text { Park }\end{array}$ & 1.4 & 0.6 & 23 & $\begin{array}{l}\text { Chaoyang Park } \\
\text { North District }\end{array}$ & 120 & 11.5 \\
\hline 9 & $\begin{array}{l}\text { Jiangtai River } \\
\text { Green Dam }\end{array}$ & 16 & 6.4 & 24 & Haidian Park & 40 & 2 \\
\hline 10 & Madian Park & 8.6 & 4.3 & 25 & $\begin{array}{l}\text { Dawn disaster } \\
\text { prevention park }\end{array}$ & 27 & 13.5 \\
\hline 11 & $\begin{array}{l}\text { Sunshine week } \\
\text { eight Park }\end{array}$ & 5.2 & 2.6 & 26 & $\begin{array}{l}\text { Changchun } \\
\text { fitness Park }\end{array}$ & 10 & 5 \\
\hline 12 & $\begin{array}{l}\text { Dongsheng Cultural } \\
\text { Sports park }\end{array}$ & 8 & 4 & 27 & Hot Spring Park & 4 & 2 \\
\hline 13 & $\begin{array}{l}\text { International } \\
\text { Sculpture Park }\end{array}$ & 40 & 11 & 28 & $\begin{array}{l}\text { Riverside } \\
\text { Century Plaza }\end{array}$ & 35 & 10 \\
\hline 14 & $\begin{array}{l}\text { Black Mountain } \\
\text { Park }\end{array}$ & 3 & 1.2 & 29 & Kang Shan Park & 4.1 & 1.8 \\
\hline 15 & Yongan Park & 6.9 & 2.8 & & & & \\
\hline
\end{tabular}


Table 3 - level types, structure and functions of disaster prevention and rescue place

\begin{tabular}{|c|c|c|}
\hline Hierarchy type & function & Main composition \\
\hline $\begin{array}{l}\text { City refuge and } \\
\text { rescue site } \\
\text { More than } 10[\mathrm{ha}] \\
\text { Service radius } \\
2-3[\mathrm{~km}]\end{array}$ & $\begin{array}{l}\text { Long term refuge life in } \\
\text { the city, disaster relief, } \\
\text { recovery and } \\
\text { reconstruction activities }\end{array}$ & $\begin{array}{l}\text { City parks, green spaces and large and } \\
\text { medium primary schools } \\
\text { The space of the campus and the large } \\
\text { stadium }\end{array}$ \\
\hline $\begin{array}{l}\text { Area refuge and } \\
\text { rescue site } \\
1-2[\text { ha] Service } \\
\text { radius } 500-600[\mathrm{~m}]\end{array}$ & $\begin{array}{l}\text { Temporary refuge and } \\
\text { rescue in disaster }\end{array}$ & $\begin{array}{l}\text { District level parks, green spaces, squares, } \\
\text { schools, sports games, etc. }\end{array}$ \\
\hline $\begin{array}{l}\text { spot refuge and } \\
\text { rescue site } \\
0.3-0.5[\text { ha }]\end{array}$ & $\begin{array}{l}\text { Emergency evacuation } \\
\text { and evacuation in the } \\
\text { disaster }\end{array}$ & $\begin{array}{l}\text { Construction site and the construction of the } \\
\text { adjacent park, green, square, parking lot, } \\
\text { open space, etc. }\end{array}$ \\
\hline
\end{tabular}

\section{The necessity of constructing the network of Disaster Prevention Green Infrastructure}

At present, under China's rapid urban expansion, high strength, high density of land use make the risk of urban disasters increases and highly concentrated. Unfortunately, both the government management departments and the community are lack of understanding of these. In China, Many cities' disaster prevention engineering standards are far lower than the United States, Japan and other developed countries, urban disaster prevention is still restricted to the construction of building monomer and security engineering research, the research based on the urban green infrastructure of disaster prevention research is too limited to adapt to the actual disaster prevention.

Green Infrastructure is was proposed by "GI working group” of the United States in 1999 and defined as "natural life support system", that is, a connected network consist of water channel, greenway, wetlands, parks, forests, farms and other protected areas that can maintaining the ecological environment and improve the quality of people' life. Past research about domestic and foreign only focus on the ecological utility, landscape utility and recreation utility of the green infrastructure but lose sight of disaster prevention utility. For example, the greenway can not only isolate the fire spreads and obstruct the collapse of the building, but also play as an emergency evacuation of the crowd and connect all levels of emergency shelters. The recovery plan for Japanese Hanshin Awaji Earthquake in 1995 propose that, refuge and disaster prevention park in the city construction should be combined with schools, hospitals, welfare institutions and other core areas of disaster prevention facilities and supporting construction for the unified layout, also, make a connection with the main roads. Meanwhile, other types of green space can also actively brought into the disaster prevention park system of city, such as green space, private space and cemetery for protection to improve the integrity of the network system (Figure 1). Therefore, the research on the function of disaster prevention city green infrastructure should be strengthened in order to fully develop the function of disaster prevention of city green infrastructure network and reduce all kinds of unexpected loss caused by sudden onset disasters.

According to the Japanese disaster prevention park system, " opinions on strengthening the construction of city green space system, improve the city disaster prevention ability " in 2008 said that, the city disaster prevention green space system should be consist by the disaster prevention park, temporary hedge green space, emergency green space, green belt buffer, greenway for evacuate the isolation. The regulation also proposed some qualitative requirements for the construction of emergency hedge green, hedge channel and emergency facilities, as for the quantitative planning requirements correspond to the elements of the new system should be further confirmed. City shelters should be built under the overall planning and establish a finished system of space. It should be hierarchical and networking, that can cover the whole city, and including municipal and district level in neighborhood. The disaster prevention area of urban level should meet the requirements of availability of $0.5 \sim 1.0$ hours reach, the service radius of $2 \sim 3 \mathrm{~km}$, also can be combined with large 
urban parks and squares (Table 3). Our country city especially large cities and mega-cities have the problems of dense buildings and population, the serious shortage of open space to avoid the disaster also made avoidance of disasters more dangerous. Take the center area of Shanghai for instance, the population density reached 40 thousand $/ \mathrm{km}^{2}, 3$ times as much as Tokyo. Once the disaster occurs, the consequences could be catastrophic. The reason why the city can work for refuge is mainly consist by concentrated and flaky green land. Japan's index of disaster prevention park is per capita green area not less than $7 \mathrm{~m}^{2}$ and large concentration refuge for $2 \mathrm{~m}^{2}$ (at least not less than $1 \mathrm{~m}^{2}$ ). According to this standard, even if the whole city public green space in our country are used as disaster prevention green space ,nearly half of the area is still lack. The research on the construction of urban green infrastructure in our country should be based on China's national conditions, and make a perfect disaster prevention green space system.

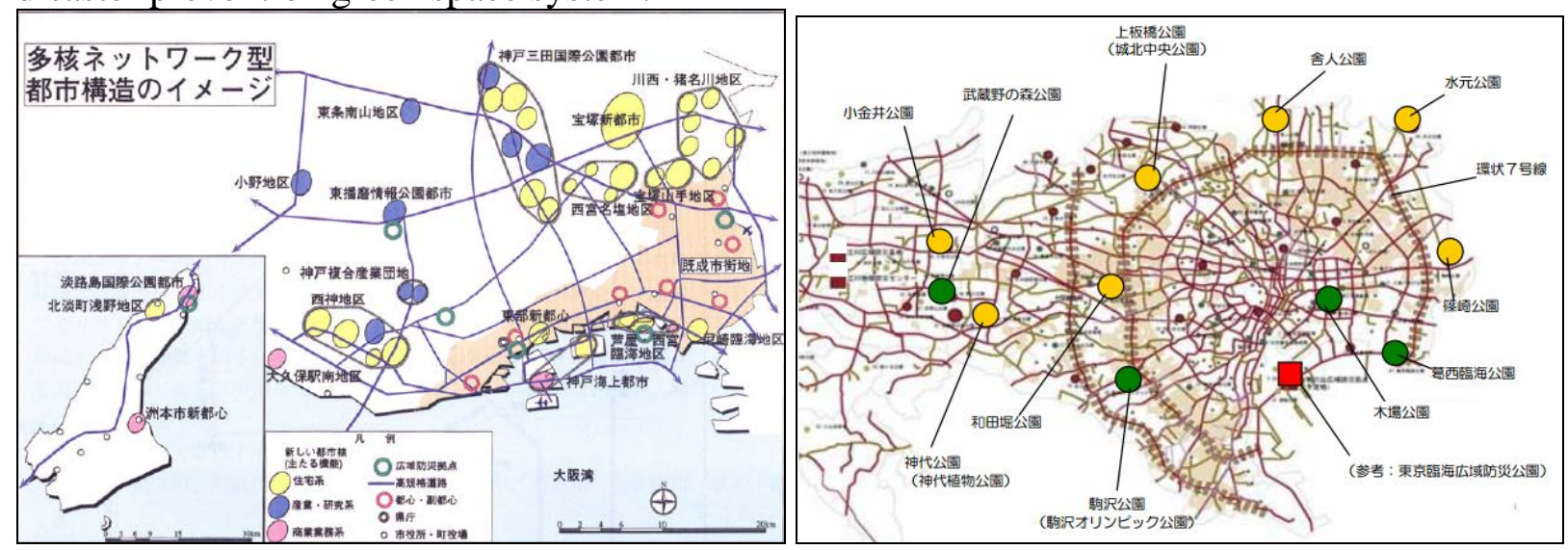

Fig. 1- KOBEI and TOKYO Area Disaster Prevention Green Space Network

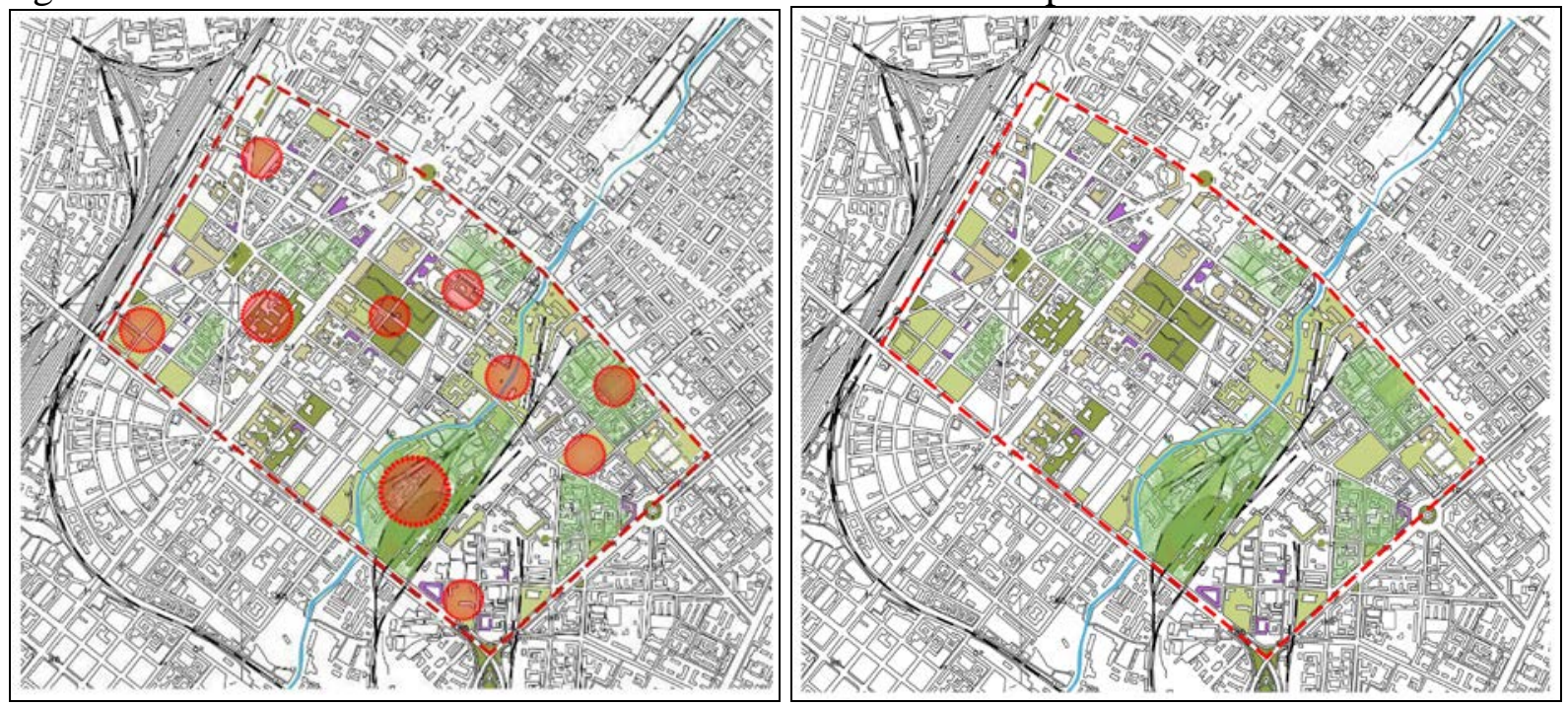

Fig. 2- Majiagou river alongside of Harbin disaster prevention green infrastructure network planning

\section{A case study of the planning of disaster prevention green infrastructure network construction of Majiagou River coast in Harbin}

Majiagou river alongside of Harbin disaster prevention green infrastructure network planning

From the overall point of view, the number of green patches in the site is seriously insufficient, the degree of fragmentation is very high while the degree of connectivity is poor, moreover, the site is serious lack of outdoor recreational activities, social interaction for residents. The association between green patches in the area and regional internal connection of the green infrastructure with other areas is not enough as well. Based on the above situation, the paper put forward three important elements for the construction of the network of Majiagou River disaster prevention green infrastructure: Urban Waterfront and Riverside, Urban Green Corridor and Urban Green Patch, the network node of these three elements is very critical in the overall network planning and should be the focus of research and analysis (Figure 2) 


\section{Summary}

First of all, improving the planning of urban disaster prevention green space and construction of the regulatory system.

Secondly, the construction of city disaster prevention green space can not merely rely on government subsidies, it needs to open up financing channels and attract more ways of capital to participate in the construction .

Finally, combining with the existing green infrastructure of city, on the base of ensuring the safety, achieving a combination usual and disaster period, functional transformation of usual and disaster period; make sure the accessibility and convenience of green infrastructure; based on the principles of long-term disaster prevention and emergency refuge.

\section{Acknowledgements}

The Project Sponsored by the "National Natural Science Foundation of China" (No.51208135)," Heilongjiang Province Science Foundation for Youths （No.QC2011C098） and "the Fundamental Research Funds for the Central Universities” (Grant No.HIT.HSS.201133).

\section{References}

[1] Feng Yao, Zhang Lusi. Study on Application of Immersion VR System into Disaster Prevention Education- Take the study on facilities for Tokyo disaster prevention education as an example, Selected Papers IDRC on Risk Reduction and Disaster Management 2010(11) :78-85

[2] Feng Yao, Zhang Lusi. Understanding of Landscape Architecture Design in Japan Advanced Materials Research, 2012(10) :2840-2845

[3] LuanWeiming, QiQige. Function and planning design of urban disaster prevention green space, [J]. Modern gardening, 2014(02):151.

[4] LuBo, YuanMing, QianQifang. Research on Suzhou urban green space disaster prevention planning based on GIS, [J]. Journal of Suzhou University of Science and Technology (NATURAL SCIENCE EDITION), 2014,04:77-81.

[5] LiJunquan, ZhuJun. The function and construction strategy of urban disaster prevention hedge green space, [J]. Modern gardening, 2015,02:145.

[6] BaoZhiyi, ChenBo. Urban green space system construction and urban disaster reduction and disaster prevention, [J]. Journal of natural disasters, 2004,02:155-160.

[7] LiJing, ZhangLang, ChenAijie. Discussion on the combination of urban emergency shelter and urban green space construction, [J]. Chinese garden, 2007,05:83-86.

[8] YouBiqing. Discussion on urban park green space system planning from urban disaster prevention_-Taking Taipei city as an example in Taiwan area, [J]. urban planning, 2004,05:74-79.

[9] QiuQiaoling, GuDequan. The comparison of the domestic and foreign disaster prevention green space and the planning and construction of urban disaster prevention green space in China, [J]. Chinese garden, 2008,12:71-75.

[10] HanXili, YuKongjian. The thought of Green channel network in urban open space planning in London, [J]. new building, 2004,05:7-9. 
